Article

\title{
Biodegradation and Absorption Technology for Hydrocarbon-Polluted Water Treatment
}

\author{
Alfonso Rodríguez-Calvo ${ }^{1}{ }^{(0)}$, Gloria Andrea Silva-Castro ${ }^{2}$, Darío Rafael Olicón-Hernández ${ }^{3}$ (D), \\ Jesús González-López ${ }^{4}$ (D) and Concepción Calvo ${ }^{4, *}$ (D) \\ 1 Environmental Microbiology Group, Institute of Water Research, University of Granada, 18071 Granada, \\ Spain; arcalvo@ugr.es \\ 2 Environmental Microbiology Group, Department of Soil Microbiology and Symbiotic Systems, University of \\ Granada, Estación Experimental del Zaidín, Consejo Superior de Investigaciones Científicas (CSIC), \\ 18008 Granada, Spain; gasilva@ugr.es \\ 3 Microbiology Department, National School of Biological Sciences, National Polytechnic Institute, \\ Mexico D.F. 11340, Mexico; magnadroh@hotmail.com \\ 4 Environmental Microbiology Group, Department of Microbiology, Institute of Water Research, University of \\ Granada, 18071Granada, Spain; jgl@ugr.es \\ * Correspondence: ccalvo@ugr.es; Tel.: +34-958-248021
}

Received: 29 November 2019; Accepted: 21 January 2020; Published: 24 January 2020

check for updates

Featured Application: The technology developed in this work based on adsorption biodegradation processes that uses meltblown polypropylene (Pad Sentec ${ }^{\mathrm{TM}}$ ) as a biosorbent is effective for the elimination of hydrocarbon compounds in the treatment of industrial polluted wastewater. The quality of the water obtained will allow the reuse of the treated water for different purposes, such as fire defense systems, which will allow for the implementation of the circular economy policy in the companies using these technologies. In this sense, in order to study the influence of operational variables such as flow rate, aeration or process time, the scaling of the system at the pilot plant level is planned.

Abstract: Wastewaters polluted with hydrocarbons are an environmental problem that has a significant impact on the natural ecosystem and on human health. Thus, the aim of this research was to develop a bioreactor sorbent technology for treating these polluted waters. A lab-scale plant composed of three 1-L bioreactors with different sorbent materials inside (meltblown polypropylene and granulated cork) was built. Wastewater to be treated was recirculated through each bioreactor for 7 days. Results showed that hydrocarbon retention rates in the three bioreactors ranged between $92.6 \%$ and $94.5 \%$ of total petroleum hydrocarbons (TPHs) and that after one simple recirculation cycle, no hydrocarbon fractions were detected by gas chromatography/Mass Spectrometry (GC/MS) in the effluent wastewater. In addition, after the wastewater treatment, the sorbent materials were extracted from the bioreactors and deposited in vessels to study the biodegradation of the retained hydrocarbons by the wastewater indigenous microbiota adhered to sorbents during the wastewater treatment. A TPH removal of $41.2 \%$ was detected after one month of Pad Sentec ${ }^{\mathrm{TM}}$ carrier treatment. Further, the shifts detected in the percentages of some hydrocarbon fractions suggested that biodegradation is at least partially involved in the hydrocarbon removal process. These results proved the efficiency of this technology for the treatment of these hydrocarbon-polluted-waters.

Keywords: biodegradation; water treatment; sorbent carriers; pilot plant; hydrocarbons 


\section{Introduction}

The presence of hydrocarbons in waters is extremely common. On some occasions, this is due to accidental spills of a greater or lesser extent and on other occasions, this is due to constant leaks from the production, storage or transport areas. As a result, hydrocarbon contamination can be often detected in water. Hydrocarbons are compounds produced by a combination of hydrogen and carbon; many of them, such as the polycyclic aromatic hydrocarbons (PAH) or benzene, toluene, ethyl benzene and the three xylenes compounds BTEX, have toxic, mutagenic and carcinogenic properties [1-3]. Hydrocarbon water pollution is an environmental problem that affects aquatic ecosystems and species, as well as their by-products. Therefore, this type of pollution, which has a significant impact on human health and the environment, attracts considerable interest and is a cause for concern not only among the scientific community but also at the social and political level [4]. Thus, in order to maintain water quality, the search for cost-effective decontamination and cleaning techniques is needed.

Some physical remediation strategies involve the use of pollutant-absorbing sorbents. Various absorbent materials have been used for the removal of oils and grease from both wastewater and the surface of seawater. In general, they are hydrophobic materials and among those available on the market, polypropylene and polyethylene compounds stand out [5]. In this sense, Pintor et al. highlight the great interest in these sorbents for the removal of oils and greases basically due to the affinity for oil, hydrophobicity and durability and because they are generally cheap and do not cause toxic by-products [6]. However, because these systems create a subsequent waste management problem technically burdensome and economically costly, different authors have proposed the use of physical-bioremediation strategies in order to reduce economic cost and environmental risks $[7,8]$.

There are different types of sorbent materials, with granular cork and meltblown polypropylene being the most important. Granular cork is a natural carrier that has demonstrated a noticeable biosorption property and is highly efficient in the removal of heavy metals and other organic pollutants such as polycyclic aromatic hydrocarbons (PAH). Granular cork is widely used as a hydrocarbon sorbent due to their high oil sorption capacity, low water retention and the possibility of reuse $[9,10]$, while meltblown polypropylene is a synthetic carrier which has a high sorption capacity and is available in several physical and chemical resistant configurations; its low density, low water uptake and its excellent physical and chemical resistance are highlighted as the main properties to choose this sorbent for water oil recovery [11].

The biological process of bioremediation removes the majority of environmental hydrocarbons through the action of microorganisms, which mineralize or convert organic compounds into less noxious and dangerous substances [12,13]. The effectiveness of bioremediation is basically due to the fact that most hydrocarbons can be degraded by microorganisms and because the degrading native microbiota is rapidly and effectively enriched in any ecosystem after the arrival of the contaminant $[14,15]$. The biodegradation potential of microorganisms isolated from oil-polluted sites is a consequence of a dynamic enrichment of degrader taxa together with a decrease in biodiversity $[2,14,15]$. Several authors have studied the use of microorganisms to break down petroleum products and have reported a wide range of degraders and how environmental factors such as available nutrients, the concentration of the contaminant, temperature, $\mathrm{pH}$ or salinity will influence the microbial activity and the diversity of the predominant microbial groups. In this sense, Röling et al. [7] reported the strong selection of bacteria from the Alcanivorax/Fundibacter groups (alkane degraders) observed during the bioremediation process in diesel-contaminated microcosms.

As microorganisms in large bodies of water can be diluted or washed away, their immobilization on a carrier could constitute an effective solution to this problem. In the biofilm, the microorganisms have a greater ability to survive, especially in periods of stress, since they are protected against environmental changes within the polysaccharide matrix, they have more accessibility to nutrients and above all, they establish microbial consortia with a wider range of metabolic activities that allow them to degrade a greater diversity of pollutants [16]. In addition, it has been reported that these microorganisms immobilized into the biofilms often enhance their hydrocarbon-degrading 
capacity [17-19]. Further, the distribution of the microbial community according to their physiological and metabolic characteristics is correlated with the gradients established along with the biofilm.

Recent studies have demonstrated that biofilm can be created on the surface of some high hydrocarbon sorption capacity materials [20]. The aim of this study was to develop an innovative treatment system for the remediation of hydrocarbon-polluted industrial wastewaters combining both absorption and biodegradation properties based on the use of biosorbent materials. The development of a new bio-sorbent system with a high retention capacity for hydrocarbons and derivatives as well as high adherence ability for degrading microorganisms, allows for the formation of biofilms with high degrading activity.

\section{Materials and Methods}

\subsection{Description of Lab-Scale Plants}

Hydrocarbon-polluted wastewater treatment was carried out in three parallel lab-scale plants. Each bioreactor was constructed with a $1 \mathrm{~L}$ glass graduated cylinder and filled with support material (33\% of the bioreactor volume) (Figure 1). Hydrocarbon-polluted industrial wastewater (25 L) was recirculated for 7 days through each bioreactor using a peristaltic pump (Watson Marlow) with a flow rate of $18 \mathrm{~L} / \mathrm{h}$ and a hydraulic retention time (HRT) of $3 \mathrm{~min} 20 \mathrm{~s}$ at $20^{\circ} \mathrm{C}$ and at $\mathrm{pH}$ of 6.7 controlled by $\mathrm{pH}$ electrode. A control assay was performed with an additional $1 \mathrm{~L}$ glass graduated cylinder without carrier working under the conditions above described.

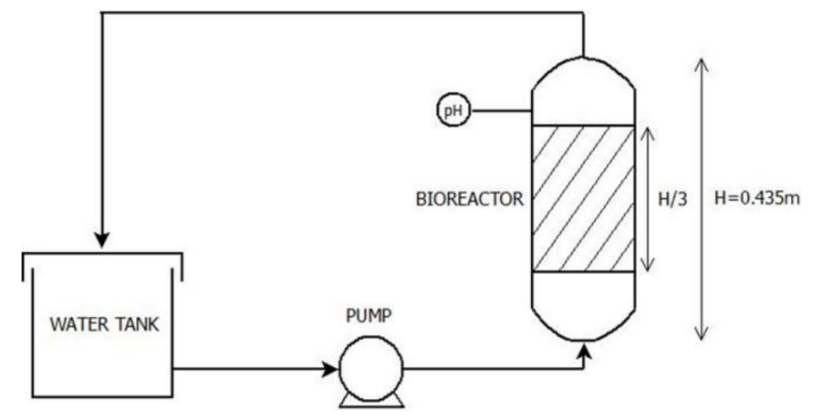

Figure 1. Scheme of the Laboratory lab-scale plant.

After operating for seven days, the carriers were deposited in three $500 \mathrm{~mL}$ capacity sterile containers (microcosms consisting on $500 \mathrm{~mL}$ covered glass beakers and in humid conditions), to evaluate the biotreatment of the sorbent carrier. The biotreatment of polluted sorbent wastes was performed in these microcosms under aerobic conditions for 8 months. The microcosms were periodically irrigated to keep adequate moisture content. All experiments were carried out in triplicate.

\subsection{Filling Materials}

Three different types of support material (Pad Sentec ${ }^{\mathrm{TM}}$, Senger Técnicas de Seguridad S.L., Madrid, Spain; CorkSorb ${ }^{\mathrm{TM}} 01025$ ADENSA, Mérida (Badajoz) Spain; and Barrier Sentec ${ }^{\mathrm{TM}}$, Senger Técnicas de Seguridad S.L., Madrid, Spain) were used. These were chosen based on their microbial adherence and hydrocarbon-adsorption capacity. Details of these materials previously reported by Rodríguez-Calvo et al. [20] are provided in Table 1. 
Table 1. Filling material characteristics.

\begin{tabular}{|c|c|c|}
\hline Filling Material & Composition & Absorption Capacity \\
\hline CorkSorb $^{\mathrm{TM}} 01025$ & $\begin{array}{l}\text { Granulated hydrophobic cork } \\
\text { (Granulometry: } 0.5-3 \mathrm{~mm} \text { ). }\end{array}$ & 9.43 L oil/kg sorbent. \\
\hline Pad Sentec ${ }^{\mathrm{TM}}$ & $\begin{array}{c}\text { Meltblown polypropylene } 99.7 \% \text {, } \\
\text { Blue pigment } 0.3 \% \text {. }\end{array}$ & $\begin{array}{l}\text { 150-200 L/1 pad (Depending on } \\
\text { the pollutant). }\end{array}$ \\
\hline Barrier Sentec ${ }^{\mathrm{TM}}$ & $\begin{array}{l}\text { Meltblown polypropylene } 90 \% \\
\text { Other no harmful fibers } 10 \% \text {. }\end{array}$ & $\begin{array}{c}30-40 \mathrm{~L} / 1 \text { barrier (Depending on } \\
\text { the pollutant). }\end{array}$ \\
\hline
\end{tabular}

\subsection{Sampling for Analytical Determination}

In this study, water and support material samples from the bioreactors were analyzed. The industrial wastewater used in the experiments came from Compañía Logística de Hidrocarburos S.A. (CLH), located in Motril, Granada (Spain), specifically from oil-storage tanks. This wastewater was characterized by an average concentration of Biological Oxygen Demand at 5 days (BOD $\left.{ }_{5}\right)$ of $320 \mathrm{mg}$ $\mathrm{O}_{2} / \mathrm{L}$ and a Chemical Oxygen Demand (COD) of $887.53 \mathrm{mg} \mathrm{O}_{2} / \mathrm{L}$. The measuring of these parameters was performed according to Standard Methods for the Examination of Waste and Wastewater [21].

Water samples $(100 \mathrm{~mL})$ were collected from wastewater influent in each bioreactor before the start of the assays (initial time), from the effluent after the first recirculation cycle and on day 1, 3 and 7 of operations in order to determine hydrocarbon concentrations. Moreover, the concentrations of hydrocarbon retained in the support materials were measured at the end of the experiment (on day 7). All experiments were carried out in triplicate.

Once the support materials were extracted from the bioreactors at day 7 of operation and deposited in sterile containers, the biodegradation of the hydrocarbons retained and the number of culturable bacteria was studied for 8 months. All experiments were carried out in triplicate.

\subsection{Quantification of Culturable Bacteria}

The number of culturable aerobic bacteria present in the support materials during the biotreatment of the sorbent carrier carried out in the sterile containers was determined using the dilution-plate technique according to Rodríguez-Calvo et al. [20].

\subsection{Isolation and Identification of Bacterial Strains}

Isolation and identification of bacterial strains were performed from the carrier samples obtained after 7 days of treatment by culture-dependent techniques. For that, ten-fold serial dilutions in sterile saline solution were performed from $1 \mathrm{~g}$ of each sample. A total of $0.1 \mathrm{~mL}$ of each dilution was spread on the Trypticase Soy Agar medium (TSA, Oxoid SA, Madrid, Spain) plate and incubated at $28^{\circ} \mathrm{C}$ for $48 \mathrm{~h}$. After the incubation time, different colonies were selected according to morphotypes features and the persistence in the replicates. Each colony was transferred to a new TSA plate. For long storage, glycerol cryo-tubes were prepared for pure cultures and kept at $-20^{\circ} \mathrm{C}$ and $-80^{\circ} \mathrm{C}$. The phylogenetic identification of isolates was performed in the Area of Nucleic Acid of the instrumental techniques laboratory of the University of León (Spain). DNA isolation was performed using PrepMan ${ }^{\mathrm{TM}}$ Ultra (Applied Biosystems) for each selected isolation. The amplification of interesting genes was carried out by polymerase chain reaction (PCR) in $50 \mu \mathrm{L}$ of reaction with DreamTaq DNA polymerase Kit (Thermo Scientific) from $1 \mu \mathrm{L}$ of DNA and $20 \mathrm{pmol}$ of each primer. The pairs of primers used were 27 F (5'-AGA GTTTGATCMTGGCTCAG-3') and 699R (5'-RGGGTTGCGCTCGTT-3') and BA-RF (5'-GAC GATCATYTWGGAAACCG-3') and BA-RR (5'-GGNGTYTCRATYGGACACAT-3').

\subsection{Hydrocarbon Analysis}

Total petroleum hydrocarbons (TPHs) were extracted from both water and carrier samples and were determined by gravimetric analysis as described elsewhere [22], using a mixture of hexane:acetone 1:1 (v/v). In the case of the carriers' samples, they were previously sonicated for $10 \mathrm{~min}$. The different 
hydrocarbon fractions were determined by gas chromatography/mass spectrometry as reported by Silva-Castro et al. [23].

\subsection{Ecotoxicity Test}

The water samples' ecotoxicity was tested according to Zucconi et al. [24], determining a cress seed (Lepidiumsativum L.) germination index (GI).

\subsection{Scanning Electron Microscopy (SEM)}

Support material samples, as previously described Rodríguez-Calvo et al. [20], were taken from the carriers, fixed with glutaraldehyde $(2.5 \% \mathrm{v} / \mathrm{v})$ followed by three phosphate buffer saline PBS washed and dehydrated using ethanol solutions. The dry carrier samples were gold coated and examined by electron microscopy.

This analysis was performed using LEO 1430VP and LEO 1430VP microscopes equipped with an INCA350 EDX system in the Centre for Scientific Instrumentation of the University of Granada (Spain).

\subsection{Statistical Analysis}

Mean values and respective standard deviations were calculated for each set of water samples from the bioreactors and support material samples from each treatment. Statistically significant differences $(p<0.05)$ were determined by analysis of variance (ANOVA) and Tukey's test. All statistical analyses were carried out using SPSS (Statistical Package for the Social Sciences) software v.15.0.

Non-metric multidimensional scaling analysis (MDS) was used to determine the distances between the polluted water treatment and the carrier biotreatment phase. Biological and chemical data were transformed to $\log (x+1)$ and used to analyze correlation matrices with similarity indices. The Euclidian model was used to compute optimal distances between treatments and filling materials. Principal component analysis (PCA) was used to highlight variation and bring out strong patterns in the parameters tested (degradation of TPH, hydrocarbon fractions concentration and indigenous microbiota) and the different support materials (Pad Sentec ${ }^{\mathrm{TM}}$, CorkSorb ${ }^{\mathrm{TM}} 01025$ and Barrier Sentec ${ }^{\mathrm{TM}}$ ) using Primer software (PRIMER-E, vs. 6.0, Plymouth, UK).

\section{Results and Discussion}

\subsection{Bioreactor Experiments}

This study was focused on the development of a new technology for the treatment of industrial wastewater polluted with hydrocarbons based on adsorption biodegradation processes. The biosorbent materials need to have efficient hydrocarbon retention, be easy to handle, not be expensive and be available in the market. According to these properties, cork sorb and propylene fiber sorbents were selected as a carrier to build the bioreactor [9,11]. Previously, the microcosm's assays demonstrated the

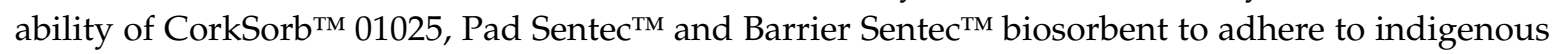
microorganisms from the polluted wastewater to the carriers' surface, making a stable biofilm [20]. In addition, it was observed that the higher the hydrocarbon content pollution was the more the microbiota adhered to the surface carrier, suggesting that the wastewater's indigenous microorganisms were tolerant of hydrocarbon pollution and could have a useful degrading capacity [20].

These assays were performed in vertical flow bioreactors, inside of which, sorbent materials were installed, taking up the entire section of bioreactor. The wastewater was recirculating from the bottom to the top of the bioreactor and the efficiency of treatment was monitored in terms of hydrocarbon removal from polluted water and the formation of biofilms on the surface carrier.

When the industrial wastewater polluted with hydrocarbons was treated in the bioreactors, hydrocarbon content, regardless of the support material used, was almost totally removed. After 7 days, $92.6 \%, 97.5 \%$ and $94.5 \%$ of total petroleum hydrocarbons (TPHs) were removed from the bioreactor filled with Pad Sentec ${ }^{\mathrm{TM}}$, CorkSorb $^{\mathrm{TM}} 01025$ and Barrier Sentec ${ }^{\mathrm{TM}}$, respectively (Figure 2). 
Among them, the Pad Sentec ${ }^{\mathrm{TM}}$ bioreactor was the most efficient as the hydrocarbon removal was reached after the first cycle of recirculation. Table 2 shows the average of the initial hydrocarbon fractions concentration in the influent; while gas chromatography/Mass Spectrometry (GC/MS) analysis revealed that after one wastewater recirculation cycle, no hydrocarbon fraction was detected in the effluent. This suggests that, in the early stages of treatment, hydrocarbon removal was the result of a physical process of the support material combined with the microbial activity. In the case of the control assay, after 7 days of treatment there was a reduction in the TPH content by $20 \%$, probably due to abiotic degradation processes. Results obtained demonstrate the high hydrocarbon retention capacity of the sorbent carriers employed. In addition, it can be suggested that this physical process was important at the beginning of the process but as the treatment was progressing, a biotransformation process was taking place in conjunction with hydrocarbon retention by the supporting material.

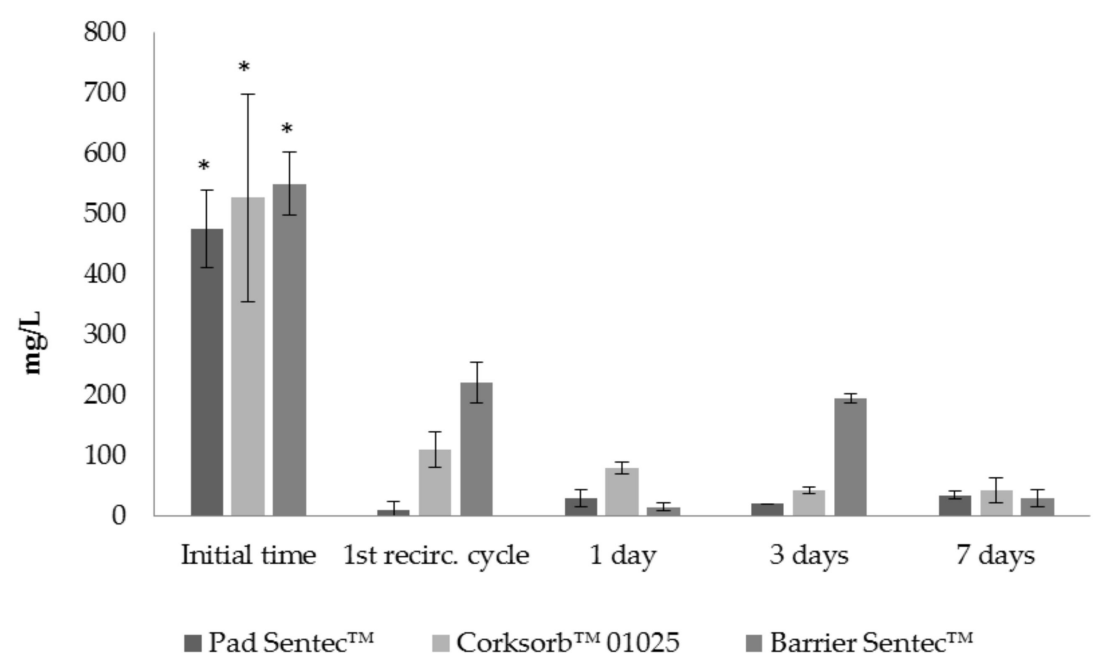

Figure 2. The time course of total petroleum hydrocarbons (TPHs) concentrations in water (mg/Lwater), using Pad Sentec ${ }^{\mathrm{TM}}$, Corksorb ${ }^{\mathrm{TM}} 01025$ and Barrier Sentec ${ }^{\mathrm{TM}}$ carrier in the influent wastewater before starting the assays (initial time) and in the effluent wastewater after the first recirculation cycle and at days 1, 3 and 7 of operation time. $\left(^{*}\right)$ Significant differences between "initial time" and the rest of the sampling times.

Table 2. Average concentrations of hydrocarbon fractions in the influent wastewater before the start of the assays (initial time).

\begin{tabular}{cc}
\hline Hydrocarbon Fraction & Average Concentration (ppm) \\
c10-c20 & $145.6 \pm 45.1$ \\
c20-c40 & $14.6 \pm 5.1$ \\
Branched/Cyclic alkanes & $21.9 \pm 6.4$ \\
Phytane & $15.5 \pm 4.0$ \\
Pristane & $19.8 \pm 7.3$ \\
Aromatics & $10.4 \pm 3.0$ \\
Alkenes & $6.7 \pm 3.8$ \\
Pregnanes & $20.9 \pm 6.8$ \\
Hahnfett & $0.0 \pm 0.0$ \\
\hline
\end{tabular}

In this sense, Bayat et al. [25] reported that the hydrocarbon absorption capacity of the meltblown polypropylene carriers was in the $7-9 \mathrm{~g} / \mathrm{g}_{\text {carrier }}$ range, with a higher amount of hydrocarbon in the water to be treated. However, we observed an absorption capacity of only 0.04 and $0.07 \mathrm{~g} / \mathrm{g}_{\text {carrier }}$ (53.2 and $109.4 \mathrm{mg} / \mathrm{L}_{\text {water }}$ ) for Pad Sentec ${ }^{\mathrm{TM}}$ and Barrier Sentec ${ }^{\mathrm{TM}}$ carriers, respectively. Gravimetric determination of TPH showed that the hydrocarbon content in the outlet wastewater after 7 days of treatment was 35.0 and $30.0 \mathrm{mg} / \mathrm{L}_{\text {water }}$, from 475.0 and $550.0 \mathrm{mg} / \mathrm{L}_{\text {water }}$ in the inlet wastewater 
using Pad Sentec ${ }^{\mathrm{TM}}$ and Barrier Sentec ${ }^{\mathrm{TM}}$ carriers, which means a theoretical removal of 440.0 and $520.0 \mathrm{mg} / \mathrm{L}_{\text {water }}$. This suggests that a share of the remaining amount of hydrocarbon was biodegraded in water and the other one was retained by the carriers and subsequently degraded by the biomass developed in the bioreactor and obviously not detected in the effluents or in the carriers.

In the same way, some studies have also reported that the sorption capacity of hydrophobic cork carriers was found to be $8-10 \mathrm{~g}$ of pollutant per gram of carrier [26]. In our study, the hydrocarbon concentration detected in the hydrophobic cork carrier was found to be only $0.08 \mathrm{~g} / \mathrm{g}_{\text {carrier }}\left(64.4 \mathrm{mg} / \mathrm{L}_{\text {water }}\right)$ after the bioreactors had been operating for 7 days. In this case, water hydrocarbon content in the inlet wastewater was $526.0 \mathrm{mg} / \mathrm{L}_{\text {water }}$ and after 7 days of treatment $107.7 \mathrm{mg} / \mathrm{L}_{\text {water }}$ and therefore the theorical removal was $418.3 \mathrm{mg} / \mathrm{L}_{\text {water, }}$, so we can consider our conclusion confirmed.

Determination of the hydrocarbon concentrations in the wastewater in the bioreactor after 7 days of treatment made it possible to verify the high removal capacity of the system (Figure 2). This demonstrates how the support materials inside the bioreactors work as highly efficient submerged filters, which was previously highlighted by some authors [27-29]. It is important to note that wastewater hydrocarbon removal was not only estimated in terms of TPH values but also in relation to the different hydrocarbon fractions studied. Further, after 7 days, hydrocarbon removal concentrations in the bioreactors were much higher than those quantified in the support material, thus suggesting that a considerable number of hydrocarbons was efficiently biodegraded by suspended or fixed biomass.

The hydrocarbon sorption efficacy of these sorbent bioreactors was similar to those reported for other sorbents such as activated carbon, grafted cellulose and clay materials, studied under different experimental designs. However, the efficacy of the sorption is markedly influenced by the experimental conditions or the operational variables [30]. In the treatment system studied, the presence of the microorganisms inside these bioreactors improves the efficiency of the system, probably due to the shift of microbial population in response to the amount of hydrocarbon retained in the sorbent and to the variation of the hydrocarbon fraction composition. Previous results carried out in microcosms [20] suggested that hydrocarbon compounds adsorbed to the surface carrier would be used as a carbon and energy source by adhering indigenous microorganisms and consequently, support their growth and be a factor that facilitates the survival of a hydrocarbon-tolerant microbiota. For this reason, it is necessary that the carrier or the sorbent materials are firstly able to retain the hydrocarbon pollutants and secondly, they are able to build a stable and metabolically active microbiota tolerant to pollutants.

In order to obtain a more complete water analysis, an ecotoxicity test was performed. Zucconi et al. [24] reported that GI values ranged from 80 to 100 are indicative of non-toxicity and values from 50 to 80 are indicative of moderate toxicity. Results from the ecotoxicity test revealed that influent wastewater could be considered as water containing free-phytotoxic substances, with a GI index above 80. Certainly, GI in water samples after 7 recirculation cycles using Pad Sentec ${ }^{\mathrm{TM}}$, CorkSorb $^{\mathrm{TM}} 01025$ and Barrier Sentec ${ }^{\mathrm{TM}}$ was around 75-78, very close to 80 , so we can assure that they are not toxic water samples (Table 3). There is not a statistically significant difference between the influent wastewater and the differently treated water samples.

Table 3. The relative germination rates (PGR), the relative growth of radicle (CRR) and germination index (GI) associated with the wastewater influent and the effluent after 7 days of operation time using Pad Sentec ${ }^{\mathrm{TM}}$, Corksorb ${ }^{\mathrm{TM}} 01025$ and Barrier Sentec ${ }^{\mathrm{TM}}$ carriers.

\begin{tabular}{|c|c|c|c|}
\hline Sample & PGR & CRR & GI \\
\hline Influent wastewater & $92.3 \pm 8.2$ & $95.5 \pm 6.8$ & $88.3 \pm 11.3$ \\
\hline Effluent (Pad Sentec ${ }^{\mathrm{TM}}$ ) & $82.3 \pm 5.8$ & $94.4 \pm 6.6$ & $77.8 \pm 5.4$ \\
\hline Effluent (CorkSorb ${ }^{\mathrm{TM}}$ 01025) & $77.8 \pm 5.2$ & $97.2 \pm 6.5$ & $75.6 \pm 5.5$ \\
\hline Effluent (Barrier Sentec ${ }^{\mathrm{TM}}$ ) & $83.3 \pm 6.0$ & $90.0 \pm 6.3$ & $75.0 \pm 5.2$ \\
\hline
\end{tabular}




\subsection{Biotreatment of Support Materials}

After 7 days of bioreactor operation, the support materials with hydrocarbons absorbed were considered as waste materials; they were removed from the bioreactors and deposited in sterile containers at controlled temperature $\left(28^{\circ} \mathrm{C}\right)$, to determine hydrocarbon degradations after 7 days, 1 and 4 and 8 months of incubation. The results of this carrier biotreatment phase showed that microbial populations were able to remain steady or grow during the assays. For Pad Sentec ${ }^{\mathrm{TM}}$, the adhering microbial population was 5.5-6.5 $\mathrm{Log}\left(\mathrm{UFC} \mathrm{mL}{ }^{-1}\right.$ ) during the assays and at around 7.5 $\log \left(\mathrm{UFC} \mathrm{mL}^{-1}\right)$ for CorkSorb ${ }^{\mathrm{TM}}$ 01025. Microbial populations adhered to Barrier Sentec ${ }^{\mathrm{TM}}$ proliferated throughout the assay to reach $8.1 \mathrm{Log}$ (UFC $\mathrm{mL}^{-1}$ ) at the end of the carrier biotreatment process (Figure 3). These results indicate that microorganisms that adhered to the three different carriers become a stable biofilm characterized by hydrocarbon tolerance.

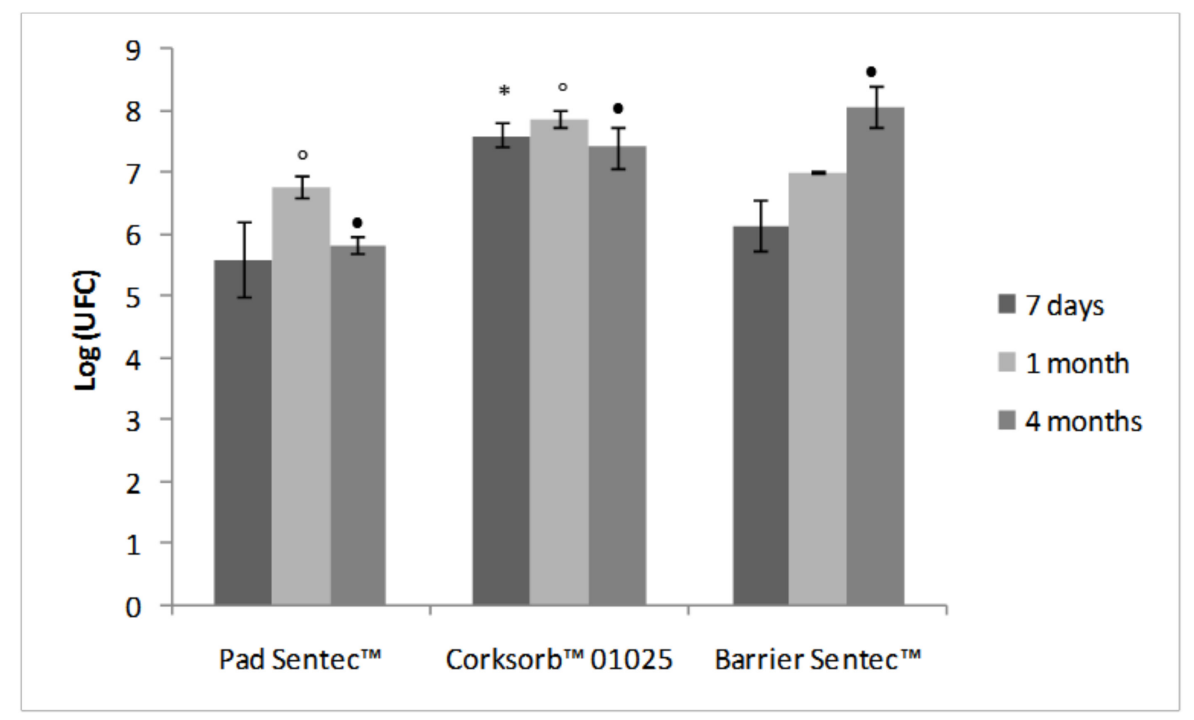

Figure 3. Indigenous microbiota adhered to Pad Sentec ${ }^{\mathrm{TM}}$, CorkSorb ${ }^{\mathrm{TM}} 01025$ and Barrier Sentec ${ }^{\mathrm{TM}}$ carriers during the carrier biotreatment phase, expressed as $\log \left(\mathrm{UFC} / \mathrm{g}\right.$ carrier). ${ }^{*}$ ) Significant differences between Corksorb ${ }^{\mathrm{TM}} 01025$ and the other carriers; $\left({ }^{\circ}\right)$ Significant differences between Pad Sentec ${ }^{\mathrm{TM}}$ and Corksorb $^{\mathrm{TM}}$ 01025; $(\bullet)$ Significant differences between Pad Sentec ${ }^{\mathrm{TM}}$, Corksorb ${ }^{\mathrm{TM}} 01025$ and Barrier Sentec ${ }^{\mathrm{TM}}$.

Albareda et al. [31] and Ferreira and Castro [32] reported that cork was a suitable material as a carrier for inocula. This has also been demonstrated by Bartowsky and Henschke [33], who verified the red wine spoilage sealed with natural cork closures by acetic acid bacteria. Several authors have also pointed out that meltblown polypropylene carriers are good candidates for bacterial adherence material [34-36]. Moreover, similar results to those of our study have been reported by several authors [37,38], who observed the development of stable biofilms in different support materials and verified their applicability to the treatment of wastewater polluted by hydrocarbons. Consequently, our results are in agreement with previous publications and suggest the biodegradative capacity of the biofilms detected in our study.

With regard to the removal of hydrocarbons absorbed by the Pad Sentec ${ }^{\mathrm{TM}}$ carrier during wastewater treatment, it was observed that an important reduction of the TPH concentrations during the 8 months of incubation in the support material was evident, however, the amount of TPH in the CorkSorb $^{\mathrm{TM}} 01025$ and Barrier Sentec ${ }^{\mathrm{TM}}$ support materials were not reduced during the experiments (Figure 4). 


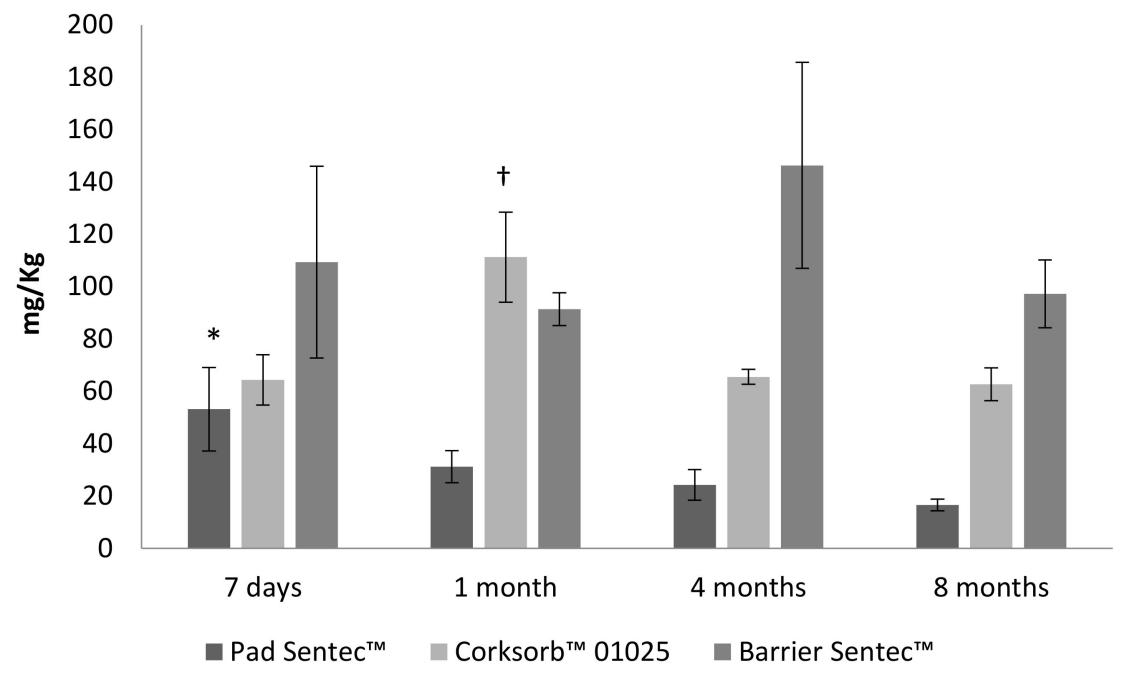

Figure 4. Time course of TPH concentrations $(\mathrm{mg} / \mathrm{Kg})$ absorbed to the Pad Sentec ${ }^{\mathrm{TM}}$, Corksorb ${ }^{\mathrm{TM}} 01025$ and Barrier Sentec ${ }^{\mathrm{TM}}$ carrier during the carrier biotreatment phase at day 7 (end of treatment phase) and after 1,4 and 8 months. ${ }^{*}$ ) Significant differences between day 7 th, 4 months and 8 months after treatment. ( $\dagger$ ) Significant differences between 1 month and the other sampling times.

Oil products are a complex mixture of hydrocarbons with different susceptibility to being degraded by microorganisms, for example, $\mathrm{n}$-alkanes are more biodegradable than branched alkanes or polycyclic aromatics compounds. Consequently, the study of the changes in the concentrations of hydrocarbon fractions through a period of biotreatments can give information about the efficiency of the bioremediation treatment with regard to the completion of hydrocarbon removal. Figure $5 \mathrm{~A}-\mathrm{C}$ shows the hydrocarbon removal during the first month of biotreatments of Pad Sentec ${ }^{\mathrm{TM}}$, Barrier Sentec ${ }^{\mathrm{TM}}$ and CorkSorb ${ }^{\mathrm{TM}} 01025$ carriers.

In Pad Sentec ${ }^{\mathrm{TM}}$ microcosms, the GC/MS analyses demonstrated that after one month of incubation of the support materials in sterile containers, the majority of the hydrocarbon fractions were almost completely removed, except for phytane and pristane. Figure 5A shows that during the first month of carrier treatment, alkanes $C_{10}-C_{20}$ were almost totally degraded. This fraction has been considered by some authors as the most easily biodegradable fraction [23,39-41] and can, therefore, be used as an accurate indicator of hydrocarbon degradation. In the same way, the increase of both branched hydrocarbons, phytane and pristane, is generally related to the biological hydrocarbon degradation.

After studying hydrocarbon degradation in the CorkSorb ${ }^{\mathrm{TM}} 01025$ and Barrier Sentec ${ }^{\mathrm{TM}}$ support materials, TPH concentrations in the materials were not reduced during the experiments (Figure 4). However, GC/MS analysis showed that some hydrocarbon fractions were removed (Figure 5B,C), suggesting the biotransformation of some hydrocarbons, such as alkanes $C_{10}-C_{20}$, to other linear and/or branched alkanes, as it has been reported by other authors [42]. In addition, the n-C18 alkane/phytane (n-C18/Ph) index revealed microbial degradation of c18 alkenes (Table 4), suggesting the hydrocarbons biotransformation in support materials during the carrier biotreatment phase, especially in the Pad Sentec microcosms where these values decrease to 0.43 after one month of treatment. The linear alkanes are easier to uptake by microorganisms than branched alkanes, thus, the decrease in the value of the $\mathrm{n}-\mathrm{C} 18 / \mathrm{Ph}$ index is usually related to the first stage of the hydrocarbon microbial degradation $[43,44]$. 


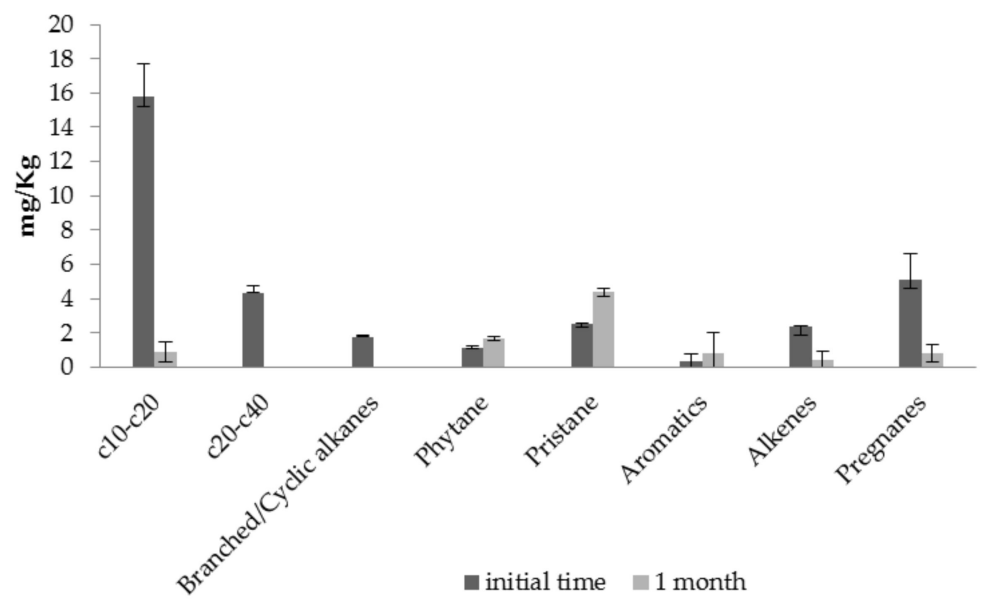

A
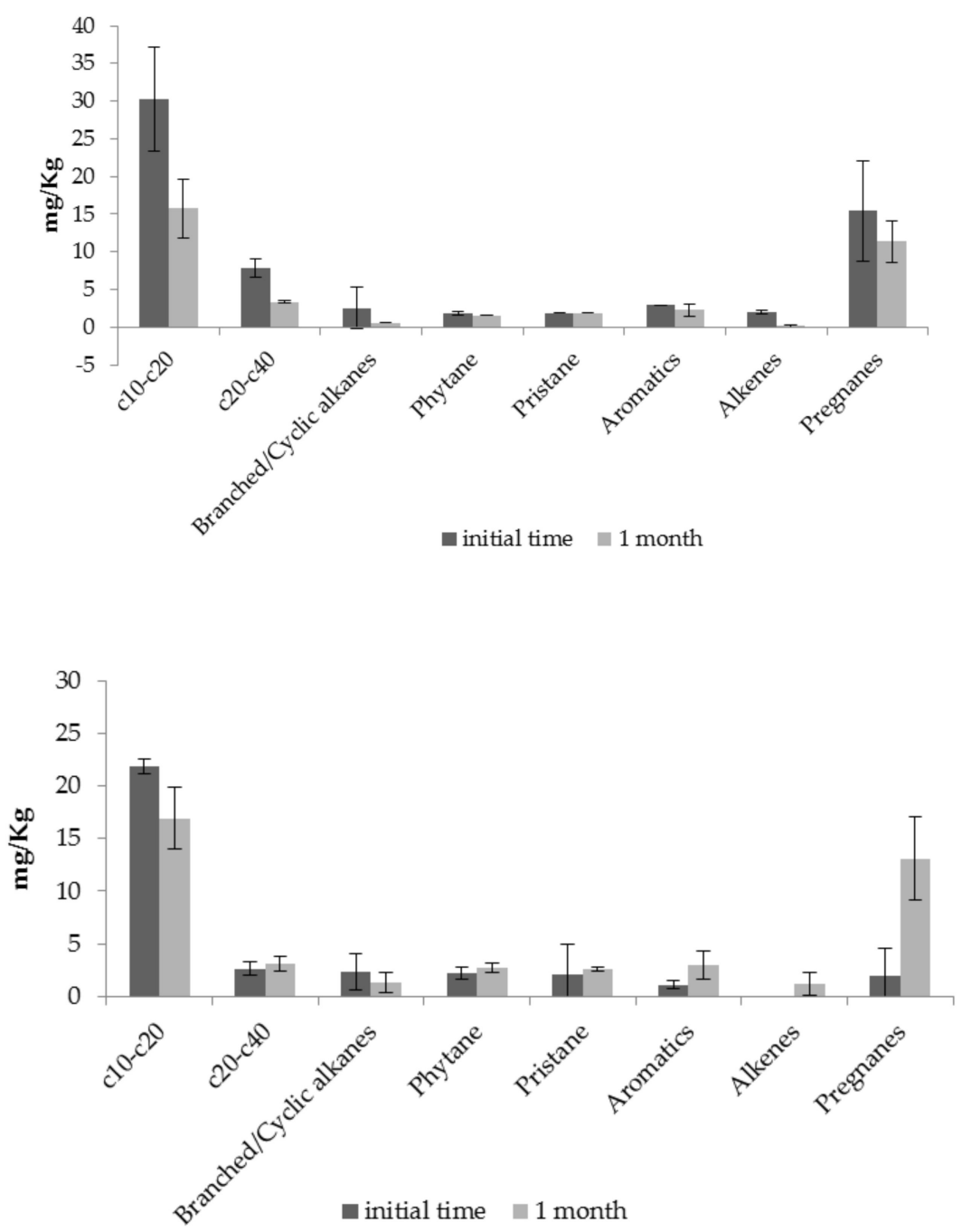

Figure 5. Time course of hydrocarbon fraction concentrations (ppm) detected by GC/MS, absorbed to the carrier during the first month of the biotreatment phase (A) Pad Sentec ${ }^{\mathrm{TM}}$ carrier, (B) Barrier Sentec $^{\mathrm{TM}}$ carrier and (C) Corksorb ${ }^{\mathrm{TM}} 01025$ carrier. 
Table 4. Time course table for $\mathrm{n}-\mathrm{C} 18$ alkane/phytane (n-C18/Ph) index associated with the three carriers during the biodegradation phase at day 7 (end of treatment phase) and after 1, 4 and 8 months.

\begin{tabular}{ccccc}
\hline n-C18/Ph & 7 Days & 1 Month & 4 Months & 8 Months \\
\hline Pad Sentec $^{\mathrm{TM}}$ & $1.3 \pm 0.3$ & $0.43 \pm 0.1$ & ND & ND \\
Corksorb $^{\mathrm{TM}} 01025$ & $1.1 \pm 0.2$ & $0.86 \pm 0.01$ & ND & ND \\
Barrier Sentec $^{\mathrm{TM}}$ & $1.4 \pm 0,2$ & $1.1 \pm 0.2$ & $0.7 \pm 0.3$ & ND \\
\hline
\end{tabular}

Evidence of hydrocarbon removal in industrial wastewater and the subsequent process of biotreatment in support materials highlight the extremely high efficiency of the bioreactors, especially when Pad Sentec ${ }^{\mathrm{TM}}$ was used. Consequently, the combination of absorption and biodegradation makes the technology used an effective system for removing hydrocarbons from polluted wastewater.

Figure 6 shows, from SEM images, the adhesion of indigenous microbiota to different carriers. When the support materials were examined microscopically, the development of considerable biofilm biomass and the stability of microbiota adhering to the carrier surface were clearly evident, suggesting that this biomass can play an important role in hydrocarbon removal.
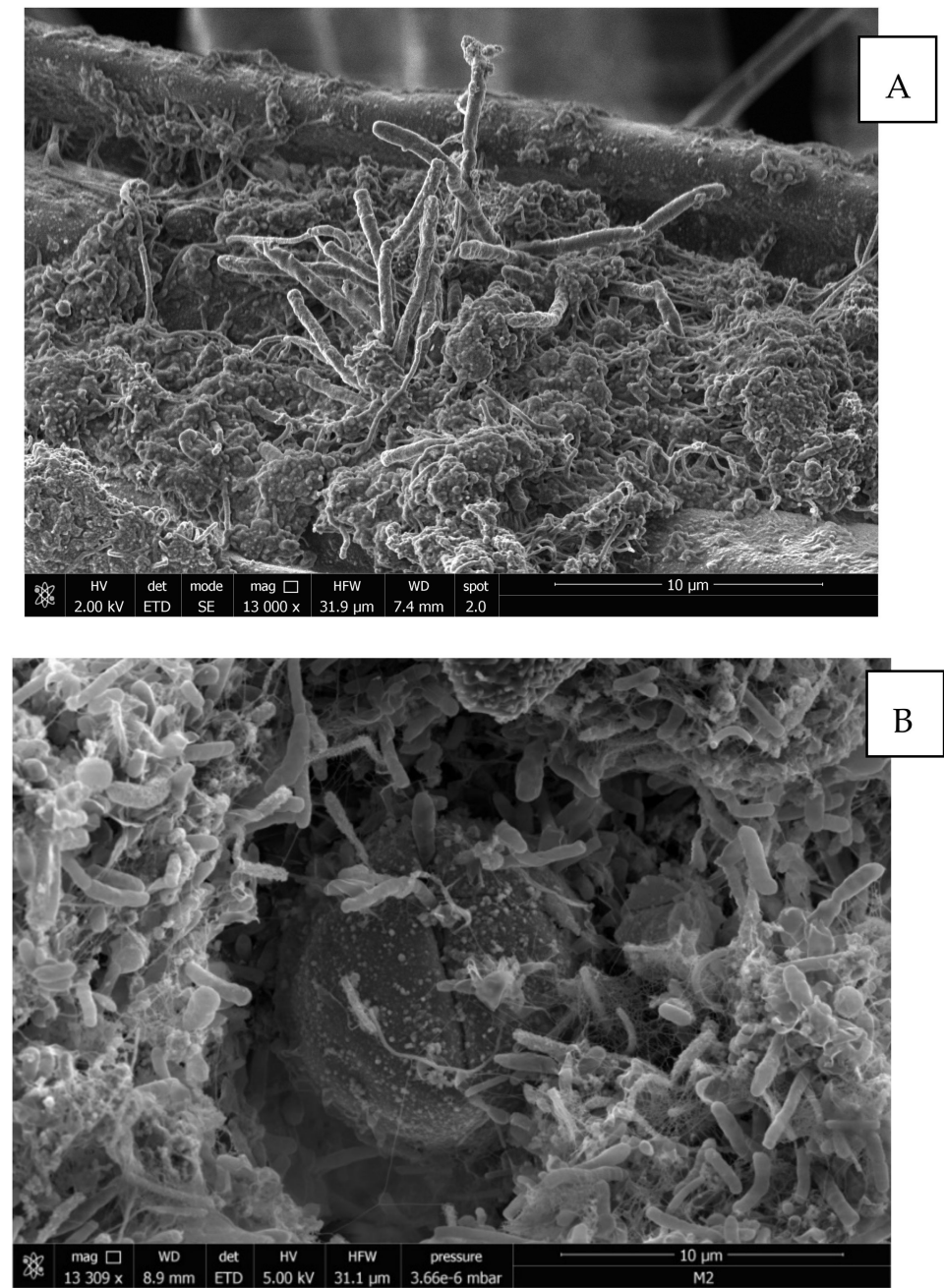

Figure 6. Cont. 


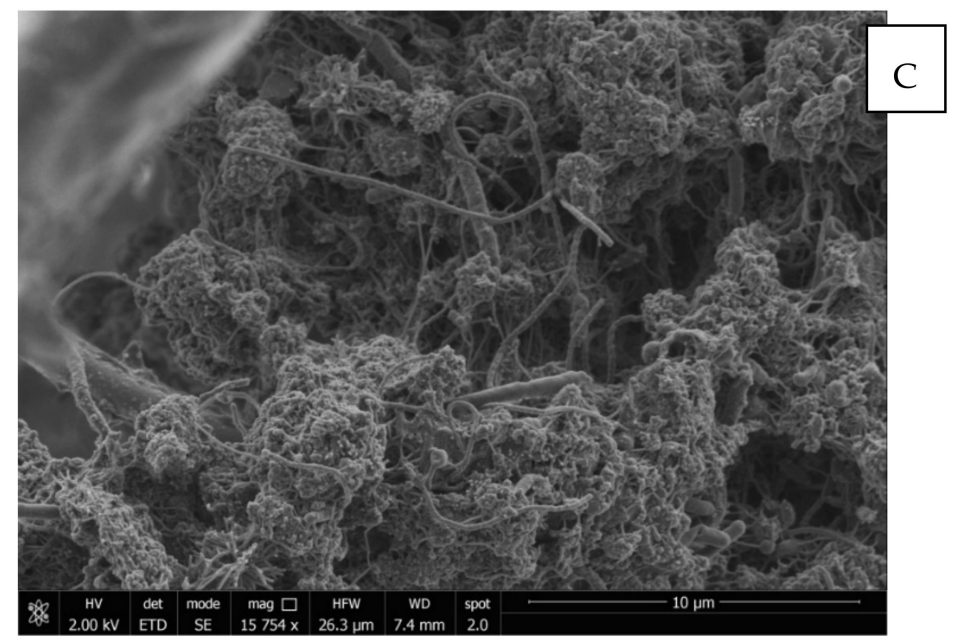

Figure 6. SEM images. General view of bacteria adhering to (A) Pad Sentec ${ }^{\mathrm{TM}}$ structure (B) CorkSorb $^{\mathrm{TM}}$ 01025 structure and $(\mathbf{C})$ Barrier Sentec ${ }^{\mathrm{TM}}$ structure during the carrier biotreatment phase after four months.

Petroleum and its derivatives are composed of a complex mixture of hydrocarbons that vary depending on physical-chemical and biological environmental factors. There are a large number of hydrocarbon-degrading microorganisms described in the literature as a result of the wide range of scenarios studied [45,46].

As mentioned, the biodegradability of hydrocarbon fractions varies according to their complexity and the microbial population is modified and influenced by these changes and environmental conditions. In this sense, it has been seen that some microorganisms found in the biofilms of reactors to treat waters highly contaminated with hydrocarbons could be good candidates for study in biodegradation, due to the fact of being present and surviving in these environments [47].

In this study, in order to have knowledge about the composition of the carrier's biofilm, an isolation of bacterial strains was performed at the beginning of biotreatment phase. Ten strains were selected as the predominant morphotypes and they were identified as Micrococcus aloeverae, Kocuriagwangalliensis, Brevibacterium casei, Gulosibacter molinativorax, Citricoccusz hacaiensis, Microbacterium sp., Microbacterium phyllosphaerae, Brevundimonas vesicularis, Brevundimonas diminuta and Microbacterium paraoxydans.

It is worth noting that some of these microorganisms, such as Brevundimonas, Gulosibacter or Kocuria, have been previously isolated from environments contaminated with hydrocarbons and they have also been described as biosurfactant producers. Biosurfactants increase the bioavailability of hydrocarbons and facilitate their biodegradation, so it is an important characteristic of the hydrocarbon-degrading microorganisms [48-50]. Accordingly, the isolated strains could be useful for building bacterial consortia capable of degrading complex mixtures of hydrocarbons and support the potential degradation capacity of biofilm formed in bioreactors [48-50]. Further, to determine the relationship between the biological and chemical parameters a multidimensional scaling (MDS) was performed to analyze the distribution of treatments (Figure 7).

The initial conditions of each treatment were clustered in group I; this group showed a high distance from group II corresponding to the data of treated water and from group III, which includes the data of hydrocarbon concentrations absorbed on the carriers. The biological and chemical parameters used to compare the efficiency of polluted water treatments (group II) did not show a statistically significant difference among the treatments at the end of the assays. However, hydrocarbons adsorbed on carriers during the carrier biotreatment showed a high variability and dispersion of data sets (group III). Based on the results obtained from the non-metric multidimensional scaling analysis (MSD) correlation analysis, principal component analysis (PCA) was used to explain the variability observed in the samples of support materials from each treatment (Figure 8). 


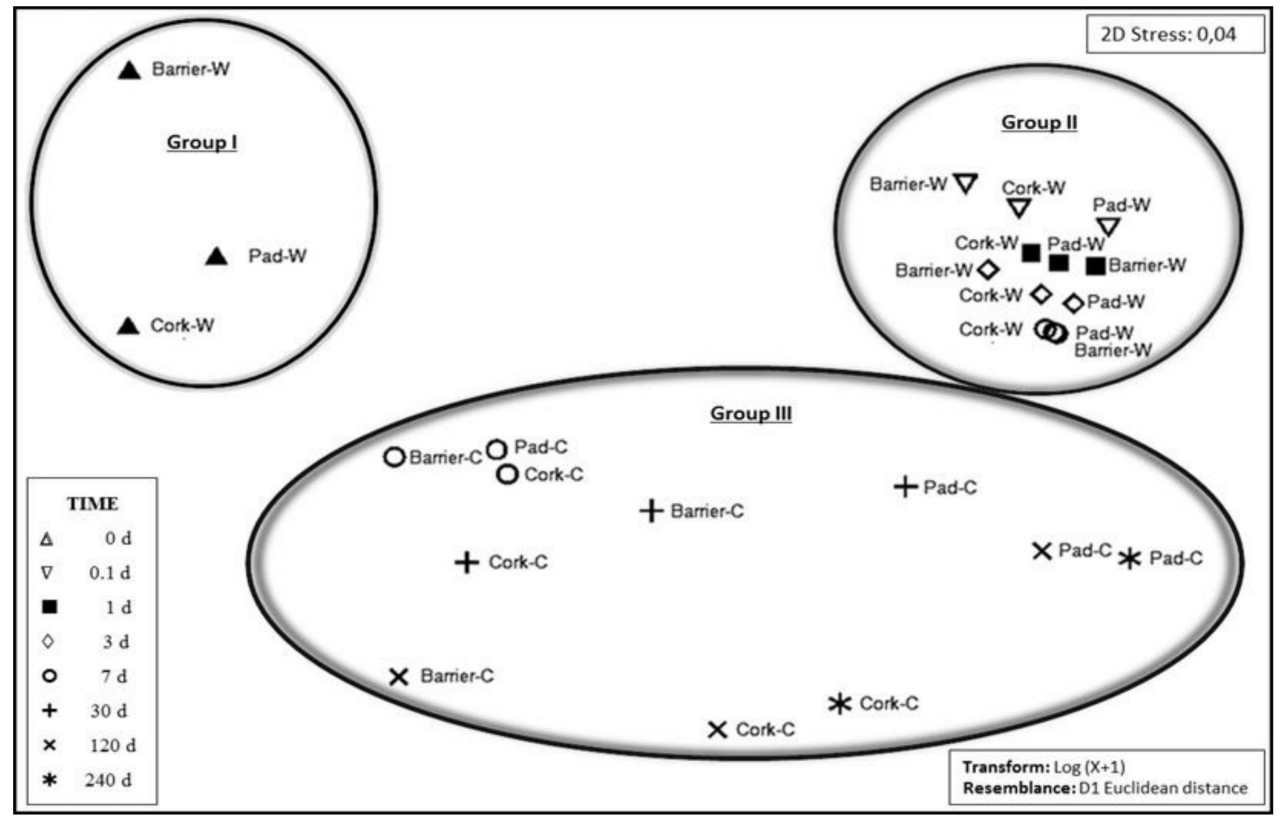

Figure 7. Optimal two dimensional configurations computed by multidimensional scaling (MDS) correlation of the water samples from the bioreactors and support material samples from each treatment.

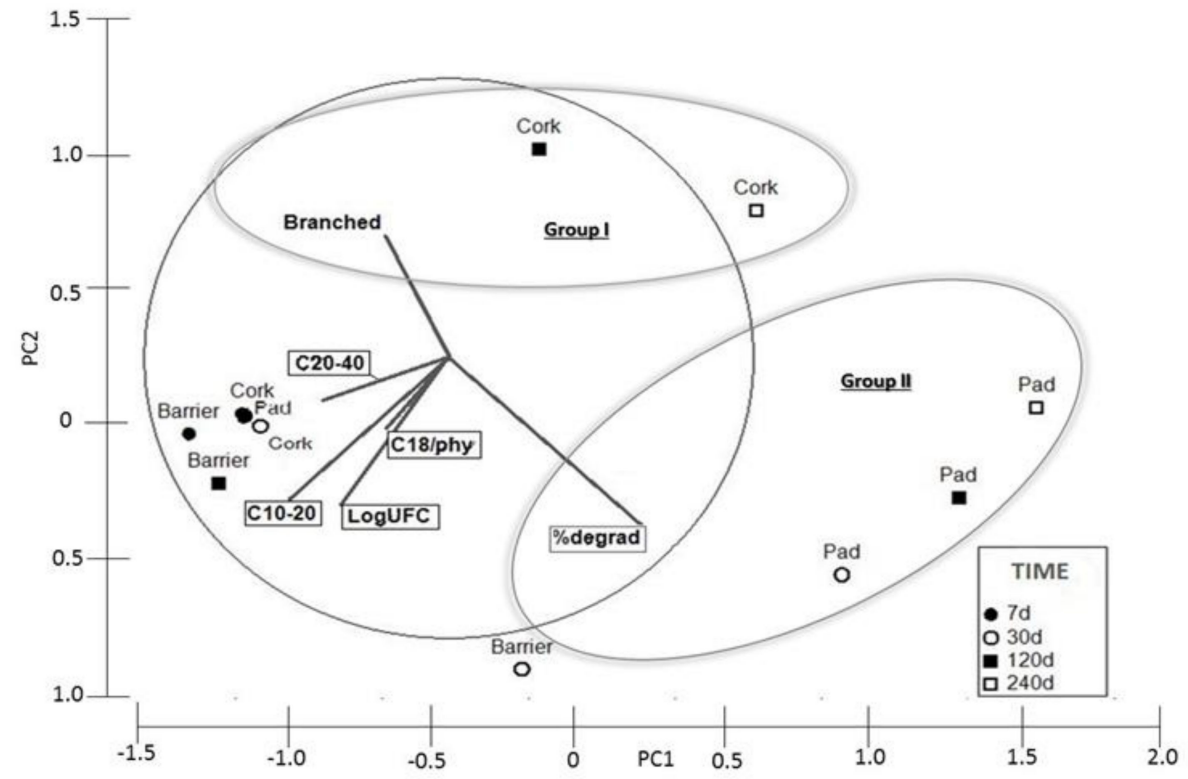

Figure 8. Principal component analysis (PCA) results for Pad Sentec ${ }^{\mathrm{TM}}$, CorkSorb ${ }^{\mathrm{TM}} 01025$ and Barrier Sentec $^{\mathrm{TM}}$ samples from each treatment, as well as biological and chemical data along straight lines for degradation of TPH, hydrocarbon fraction concentrations and indigenous microbiota.

The percentages of TPH and branched alkanes degradation were found to be the major factors explaining the variability in each one of the support material. The plot shows the clear link between the Pad Sentec ${ }^{\mathrm{TM}}$ carrier and the TPH degradation rate during the assay (circle II). On the other hand, the high degradation of the branched fraction was associated with the CorkSorb ${ }^{\mathrm{TM}} 01025$ carrier after 120 days of treatment (circle I).

The difference between the CorkSorb ${ }^{\mathrm{TM}} 01025$ and Pad Sentec ${ }^{\mathrm{TM}}$ carriers depends on the adsorption capacity and the accessibility to the carrier surface. In the case of CorkSorb ${ }^{\mathrm{TM}} 01025$, the hydrophobic character is mainly responsible for the process of sorption of the hydrocarbon fractions, especially the 
branched ones and is due to its main components (lignin and polysaccharides) in the primary wall, however, the presence of cork waxes (aliphatic extracts) inside it hinders the absorption of other fractions. For this reason, the presence of biomass increases the accessibility of these contaminates through the cork cell wall [51].

On the other hand, the Pad Sentec ${ }^{\mathrm{TM}}$ is a web of individual fibers that contains small pores that facilitate the transport of contaminated water and also retains the particles after absorption. The hydrocarbon retention depends on the porosity of the fiber; a higher porosity has a higher initial absorption but a low retention capacity. The hydrocarbon release rate can be reduced with thinner fibers [11]. In this study the retention capacity of hydrocarbons in the Pad Sentec ${ }^{\mathrm{TM}}$ was reduced by the formation of biofilm, increasing its yield.

Given the results for both phases in terms of the hydrocarbon reduction in water absorbed by carriers, as well as the evolution of the $\mathrm{n}-\mathrm{C} 18 / \mathrm{Ph}$ index, the Pad Sentec ${ }^{\mathrm{TM}}$ carrier was found to be the best option for treating hydrocarbon-polluted waters. In addition, the technology developed constitutes an effective system for the treatment of hydrocarbon-polluted waters which combines both absorption and biodegradation techniques.

\section{Conclusions}

The novelty of this technology is based on the selection of indigenous degraders based on their high hydrocarbon concentration on the carrier surface. The capacity of sorbent material to adhere to hydrocarbon pollutants on its surface acts as an enrichment technique for enhancing the ratio of degraders with respect to total microbiota. The treatment system studied is effective in the treatment of industrial wastewater contaminated with hydrocarbons. Corksorb and Pad Sentec ${ }^{\mathrm{TM}}$ hydrophobic sorbents allow the formation of a stable biofilm tolerant of high concentrations of hydrocarbons.

Author Contributions: Conceptualization, A.R.-C., G.A.S.-C., J.G.-L. and C.C.; statistical validation and supervision, D.R.O.-H., G.A.S.-C. and A.R.-C.; methodology, formal analyses and investigation, A.R.-C., G.A.S.-C., J.G.-L. and C.C.; writing-review and editing, A.R.-C., G.A.S.-C., D.R.O.-H., J.G.-L. and C.C.; supervision, C.C. and J.G.-L.; project administration and funding acquisition, C.C. All authors have read and agreed to the published version of the manuscript.

Funding: This research was funded by Compañía Logística de Hidrocarburos S.A. and Dario Rafael Olicón-Hernández was funding by Consejo Nacional de Ciencia y Tecnología of Mexico (CONACyT) for the postdoc fellowships (231581/454815.

Acknowledgments: The authors would like to acknowledge theEnvironmental Microbiology Research Group[RNM-270] of theUniversity of Granada (Spain). Also, we acknowledge Proof-Reading-Service.com (UK) for improving the English in the manuscript.

Conflicts of Interest: The authors declare no conflict of interest.

\section{References}

1. Haritash, A.K.; Kaushik, C.P. Biodegradation aspects of Polycyclic Aromatic Hydrocarbons (PAHs): A review. J. Hazard. Mater. 2009, 169, 1-15. [CrossRef]

2. Pandey, P.; Pathak, H.; Dave, S. Microbial Ecology of Hydrocarbon Degradation in the Soil: A Review. Res. J. Environ. Toxicol. 2016, 10,1-15. [CrossRef]

3. Zhang, Y.; Yang, X.; Gu, C.; Wang, F.; Bian, Y.; Song, Y.; Wang, D.; Jiang, X. A novel bioaccessibility prediction method for PAHs in soil: Composite extraction with hydroxypropyl- $\beta$-cyclodextrin and extracellular polymer substances. Sci. Total Environ. 2016, 569, 997-1003. [CrossRef] [PubMed]

4. Soliman, R.M.; El-Gendy, N.S.; Deriase, S.F.; Farahat, L.A.; Mohamed, A.S. The Evaluation of Different Bioremediation Processes for Egyptian Oily Sludge Polluted Soil on a Microcosm Level. Energy Sources Part A Recovery Utilization Environ. Eff. 2014, 36, 231-241. [CrossRef]

5. Pintor, A.M.A.; Vilar, V.J.P.; Botelho, C.M.S.; Boaventura, R.A.R. Oil and grease removal from wastewaters: Sorption treatment as an alternative to state-of-the-art technologies. A critical review. Chem. Eng. J. 2016, 297, 229-255. [CrossRef] 
6. Saleem, J.; Adil Riaz, M.; Gordon, M. Oil sorbents from plastic wastes and polymers: A review. J. Hazard. Mater. 2018, 341, 424-437. [CrossRef]

7. Röling, W.F.M.; Milner, M.G.; Jones, D.M.; Lee, K.; Daniel, F.; Swannell, R.J.P.; Head, I.M. Robust Hydrocarbon Degradation and Dynamics of Bacterial Communities during Nutrient-Enhanced Oil Spill Bioremediation. Appl. Environ. Microbiol. 2002, 68, 5537-5548. [CrossRef]

8. Vieira, P.A.; Vieira, R.B.; de França, F.P.; Cardoso, V.L. Biodegradation of effluent contaminated with diesel fuel and gasoline. J. Hazard. Mater. 2007, 140, 52-59. [CrossRef]

9. Pintor, A.M.A.; Ferreira, C.I.A.; Pereira, J.C.; Correia, P.; Silva, S.P.; Vilar, V.J.P.; Botelho, C.M.S.; Boaventura, R.A.R. Use of cork powder and granules for the adsorption of pollutants: A review. Water Res. 2012, 46, 3152-3166. [CrossRef]

10. Vilar, V.; Ferreira, C.I.D.A.; Pereira, J.; Pintor, A.; Botelho, C.; Martins, R.; Órfão, J.; Boaventura, R.; Correia, P.; Silva, S. Utilização de resíduos ou subprodutos de cortiça para a eliminação de óleos e gorduras de águas. In Encontro Brasileiro sobre Adsorção (EBA9) e Congresso Ibero-Americano sobre Adsorção (IBA1); Polytechnic Institute of Bragança: Bragança, Portugal, 2012; Volume 1, pp. 2-6.

11. Wei, Q.F.; Mather, R.R.; Fotheringham, A.F.; Yang, R.D. Evaluation of nonwoven polypropylene oil sorbents in marine oil-spill recovery. Mar. Pollut. Bull. 2003, 46, 780-783. [CrossRef]

12. Margesin, R.; Schinner, F. Biodegradation and bioremediation of hydrocarbons in extreme environments. Appl. Microbiol. Biotechnol. 2001, 56, 650-663. [CrossRef] [PubMed]

13. McGenity, T.J.; Folwell, B.D.; McKew, B.A.; Sanni, G.O. Marine crude-oil biodegradation: A central role for interspecies interactions. Aquat. Biosyst. 2012, 8, 10. [CrossRef] [PubMed]

14. Dellagnezze, B.M.; de Sousa, G.V.; Martins, L.L.; Domingos, D.F.; Limache, E.E.G.; de Vasconcellos, S.P.; da Cruz, G.F.; de Oliveira, V.M. Bioremediation potential of microorganisms derived from petroleum reservoirs. Mar. Pollut. Bull. 2014, 89, 191-200. [CrossRef] [PubMed]

15. Guibert, L.M.; Loviso, C.L.; Marcos, M.S.; Commendatore, M.G.; Dionisi, H.M.; Lozada, M. Alkane Biodegradation Genes from Chronically Polluted Subantarctic Coastal Sediments and Their Shifts in Response to Oil Exposure. Microb. Ecol. 2012, 64, 605-616. [CrossRef] [PubMed]

16. Radwan, S.S.; Al-Hasan, R.H.; Salamah, S.; Al-Dabbous, S. Bioremediation of oily sea water by bacteria immobilized in biofilms coating macroalgae. Int. Biodeterior. Biodegrad. 2002, 50, 55-59. [CrossRef]

17. Singh, R.; Paul, D.; Jain, R.K. Biofilms: Implications in bioremediation. Trends Microbiol. 2006, 14, $389-397$. [CrossRef]

18. Chandran, P.; Das, N. Degradation of diesel oil by immobilized Candida tropicalis and biofilm formed on gravels. Biodegradation 2011, 22, 1181-1189. [CrossRef]

19. Al-Kharusi, S.; Abed, R.M.M.; Dobretsov, S. Changes in respiration activities and bacterial communities in a bioaugmented oil-polluted soil in response to the addition of acyl homoserine lactones. Int. Biodeterior. Biodegrad. 2016, 107, 165-173. [CrossRef]

20. Rodríguez-Calvo, A.; Silva-Castro, G.A.; Robledo-Mahón, T.; González-López, J.; Calvo, C. Capacity of Hydrophobic Carriers to Form Biofilm for Removing Hydrocarbons from Polluted Industrial Wastewater: Assay in Microcosms. Water Air Soil Pollut. 2018, 229, 175. [CrossRef]

21. APHA (American Public Health Association) Standard Methods for the Examination of Water and Waste Water; American Public Health Association: Washington, DC, USA, 2005.

22. Aguilera-Vázquez, L.; Soto-Cruz, N.O.; Saucedo-Castañeda, G.; Gutiérrez-Rojas, M. A model system for cocomposting hydrocarbon contaminated soil by using water activity and porosity as response variables. Chem. Eng. J. 2001, 81, 197-202. [CrossRef]

23. Silva-Castro, G.A.; Rodriguez-Calvo, A.; Laguna, J.; González-López, J.; Calvo, C. Autochthonous microbial responses and hydrocarbons degradation in polluted soil during biostimulating treatments under different soil moisture. Assay in pilot plant. Int. Biodeterior. Biodegrad. 2016, 108, 91-98. [CrossRef]

24. Zucconi, F.; Pera, A.; Forte, M.; De Bertoldi, M. Evaluating toxicity of immature compost. BioCycle 1981, 22, 54-57.

25. Bayat, A.; Aghamiri, S.F.; Moheb, A.; Vakili-Nezhaad, G.R. Oil Spill Cleanup from Sea Water by Sorbent Materials. Chem. Eng. Technol. 2005, 28, 1525-1528. [CrossRef]

26. Bazargan, A.; Hui, C.W.; Mckay, G. Marine residual fuel sorption and desorption kinetics by alkali treated rice husks. Cellulose 2014, 21, 1997-2006. [CrossRef] 
27. Gómez, M.A.; González-López, J.; Hontoria-Garcdía, E. Influence of carbon source on nitrate removal of contaminated groundwater in a denitrifying submerged filter. J. Hazard. Mater. 2000, 80, 69-80. [CrossRef]

28. Gómez-Villalba, B.; Calvo, C.; Vilchez, R.; González-López, J.; Rodelas, B. TGGE analysis of the diversity of ammonia-oxidizing and denitrifying bacteria in submerged filter biofilms for the treatment of urban wastewater. Appl. Microbiol. Biotechnol. 2006, 72, 393-400. [CrossRef]

29. Moreno, B.; Gómez, M.A.; González-López, J.; Hontoria, E. Inoculation of a submerged filter for biological denitrification of nitrate polluted groundwater: A comparative study. J. Hazard. Mater. 2005, 117, 141-147. [CrossRef]

30. Lamichhane, S.; Bal Krishna, K.C.; Sarukkalige, R. Polycyclic aromatic hydrocarbons (PAHs) removal by sorption: A review. Chemosphere 2016, 148, 336-353. [CrossRef]

31. Albareda, M.; Rodríguez-Navarro, D.N.; Camacho, M.; Temprano, F.J. Alternatives to peat as a carrier for rhizobia inoculants: Solid and liquid formulations. Soil Biol. Biochem. 2008, 40, 2771-2779. [CrossRef]

32. Ferreira, E.M.; Castro, I.E. Residues of the Cork Industry as Carriers for the Production of Legume Inoculants. Silva. Lusit. 2005, 13, 159-167.

33. Bartowsky, E.J.; Henschke, P.A. Acetic acid bacteria spoilage of bottled red wine-A review. Int. J. Food Microbiol. 2008, 125, 60-70. [CrossRef] [PubMed]

34. Jurecska, L.; Barkács, K.; Kiss, É.; Gyulai, G.; Felföldi, T.; Törő, B.; Kovács, R.; Záray, G. Intensification of wastewater treatment with polymer fiber-based biofilm carriers. Microchem. J. 2013, 107, 108-114. [CrossRef]

35. Krivorot, M.; Kushmaro, A.; Oren, Y.; Gilron, J. Factors affecting biofilm formation and biofouling in membrane distillation of seawater. J. Membr. Sci. 2011, 376, 15-24. [CrossRef]

36. Zhou, D.; Hai, R.; Wang, W. Novel Complex Fiber Biofilm Carrier in an Anaerobic/Anoxic/Oxic Reactor for Sewage Mixture Treatment. Asian J. Chem. 2013, 25, 6943-6947. [CrossRef]

37. Rosenberg, M. Microbial adhesion to hydrocarbons: Twenty-five years of doing MATH. FEMS Microbiol. Lett. 2006, 262, 129-134. [CrossRef] [PubMed]

38. Abarian, M.; Hassanshahian, M.; Badoei-Dalfard, A. Isolation, Screening, and Characterization of Naphthalene-Degrading Bacteria from Zarand Mine, Iran. Polycycl. Aromat. Compd. 2018, 38, 410-419. [CrossRef]

39. Admon, S.; Green, M.; Avnimelech, Y. Biodegradation Kinetics of Hydrocarbons in Soil during Land Treatment of Oily Sludge. Bioremed. J. 2001, 5, 193-209. [CrossRef]

40. Leahy, J.G.; Colwell, R.R. Microbial degradation of hydrocarbons in the environment. Microbiol. Mol. Biol. Rev. 1990, 54, 305-315. [CrossRef]

41. Mishra, S.; Jyot, J.; Kuhad, R.C.; Lal, B. Evaluation of Inoculum Addition to Stimulate in Situ Bioremediation of Oily-Sludge-Contaminated Soil. Appl. Environ. Microbiol. 2001, 67, 1675-1681. [CrossRef]

42. Abbasian, F.; Lockington, R.; Mallavarapu, M.; Naidu, R. A Comprehensive Review of Aliphatic Hydrocarbon Biodegradation by Bacteria. Appl. Biochem. Biotechnol. 2015, 176, 670-699. [CrossRef]

43. Asif, M.; Grice, K.; Fazeelat, T. Assessment of petroleum biodegradation using stable hydrogen isotopes of individual saturated hydrocarbon and polycyclic aromatic hydrocarbon distributions in oils from the Upper Indus Basin, Pakistan. Org. Geochem. 2009, 40, 301-311. [CrossRef]

44. Shelton, J.L.; McIntosh, J.C.; Warwick, P.D.; McCray, J.E. Impact of formation water geochemistry and crude oil biodegradation on microbial methanogenesis. Org. Geochem. 2016, 98, 105-117. [CrossRef]

45. Varjani, S.J.; Upasani, V.N. A new look on factors affecting microbial degradation of petroleum hydrocarbon pollutants. Int. Biodeterior. Biodegrad. 2017, 120, 71-83. [CrossRef]

46. Xue, J.; Yu, Y.; Bai, Y.; Wang, L.; Wu, Y. Marine Oil-Degrading Microorganisms and Biodegradation Process of Petroleum Hydrocarbon in Marine Environments: A Review. Curr. Microbiol. 2015, 71, 220-228. [CrossRef]

47. Wang, X.; Wang, X.; Liu, M.; Bu, Y.; Zhang, J.; Chen, J.; Zhao, J. Adsorption-synergic biodegradation of diesel oil in synthetic seawater by acclimated strains immobilized on multifunctional materials. Mar. Pollut. Bull. 2015, 92, 195-200. [CrossRef]

48. Naeem, A.H.; Mumtaz, S.; Haleem, A.; Qazi, M.A.; Malik, Z.A.; Dasti, J.I.; Ahmed, S. Isolation and Molecular Characterization of Biosurfactant-Producing Bacterial Diversity of Fimkassar Oil Field, Pakistan. Arab. J. Sci. Eng. 2017, 42, 2349-2359. [CrossRef]

49. Mahjoubi, M.; Jaouani, A.; Guesmi, A.; Ben Amor, S.; Jouini, A.; Cherif, H.; Najjari, A.; Boudabous, A.; Koubaa, N.; Cherif, A. Hydrocarbonoclastic bacteria isolated from petroleum contaminated sites in 
Tunisia: Isolation, identification and characterization of the biotechnological potential. New Biotechnol. 2013, 30, 723-733. [CrossRef]

50. Guermouche M'rassi, A.; Bensalah, F.; Gury, J.; Duran, R. Isolation and characterization of different bacterial strains for bioremediation of n-alkanes and polycyclic aromatic hydrocarbons. Environ. Sci. Pollut. Res. 2015, 22, 15332-15346. [CrossRef]

51. Olivella, M.À.; Jové, P.; Bianchi, A.; Bazzicalupi, C.; Cano, L. An integrated approach to understanding the sorption mechanism of phenanthrene by cork. Chemosphere 2013, 90, 1939-1944. [CrossRef]

(C) 2020 by the authors. Licensee MDPI, Basel, Switzerland. This article is an open access article distributed under the terms and conditions of the Creative Commons Attribution (CC BY) license (http://creativecommons.org/licenses/by/4.0/). 